\title{
DINAMIKA AKSES INFORMASI WISATAWAN ANTAR GENERASI PADA OBYEK WISATA MINAT KHUSUS DI KABUPATEN BANTUL
}

\author{
Fian Damasdino \\ NIDN. 0525098901 \\ Email: fian@ampta.ac.id \\ Dosen Sekolah Tinggi Pariwisata AMPTA Yogyakarta
}

\begin{abstract}
Every generation of human has unique experience use information and communication technology. Each generation has different characteristics, such as knowledge, experience and expertise in interacting with the media access to information not only electronic media but also print media and online media.

This research is a kind of quantitative research with survey research method. The research location in 10 tourism destination in Bantul: Banyunibo Waterfall in Pajangan, Mangunan, Pine Forest, Siluk Suspension Bridge in Imogiri, Geospatial Coastal Dune Sand in Parangtritis, Becici Hill in Dlingo, Pulosari Waterfall in Pajangan, Watu Lumbung in Parangtritis, Tri Panjung Hill in Dlingo, Lepo Lake in Dlingo, and Mangunan Hill in Dlingo.

Sampling using non probbably sampling technique because the population in this research is not known for certain. This is due to the absence of data collection of visitor tourist by the local government. Sampling was conducted during May-September 2016 at 10 tourism destination. The collection of data taken with questionnaires, observation, and documentation library. Once the data is collected and processed by quantitative analysis using statistical tools, frequency distributions and cross tables (crosstabs).
\end{abstract}

Keywords: information access, human generation, special interest tourism

\section{PENDAHULUAN}

Perkembangan teknologi informasi dan komunikasi (TIK) di era globalisasi ini memberikan andil yang besar bagi peradaban umat manusia. Kehadiran TIK telah memberikan kemudahan dan keleluasaan bagi penggunanya, tidak hanya dalam hal mendapatkan informasi tetapi juga kemudahan dalam berinteraksi. Internet memberikan akses yang hampir tidak terbatas bagi peradaban umat manusia.

Ledakan teknologi informasi dan komunikasi (TIK) tersebut telah membuka babak baru bagi masyarakat untuk memperoleh informasi secara bebas. Sekat-sekat informasi dengan sendirinya menghilang oleh inisiatif kuat dari setiap individu yang ingin mengetahui lebih jauh apa yang terjadi sekitarnya. Setiap orang memiliki akses untuk bisa mendapatkan berbagai informasi dari banyak media, seperti televisi, internet, dan sosial media. Akses informasi paling banyak yang dilakukan di globalisasi ini adalah melalui internet. Akses melalui internet merupakan saat ini banyak dimanfaatkan oleh generasi manusia sebagai sarana yang paling efektif dan efisien dalam menunjang kegiatan akses informasi dalam bidang apapun.

Sebelum internet berkembang, generasi manusia menggunakan media elektronik dan media cetak seperti televisi, radio dan surat kabar sebagai media untuk membantu mereka mendapatkan dan mencari kebutuhan informasinya, kini melalui media online semua orang dengan mudah mendapatkan kebutuhan tersebut tanpa ada batasan ruang, waktu, usia, suku, agama, budaya maupun batasan-batasan lainnya yang dapat menghambat upaya mendapatkan kebutuhan informasi.

Survei yang dilakukan sepanjang 2016 itu menemukan bahwa 132,7 juta orang Indonesia telah terhubung ke internet. Adapun total penduduk Indonesia sendiri sebanyak 256,2 juta orang. Hal ini mengindikasikan kenaikan 51,8 persen dibandingkan jumlah pengguna internet pada 2014 lalu. Survei yang dilakukan Asosiasi Penyelenggara Jaringan Internet Indonesia (APJII) pada 2014 hanya ada 88 juta pengguna internet (Widiartanto, 2016). Internet menjadi salah satu media yang paling banyak diakses oleh masyarakat Indonesia.

Kehadiran internet membawa manusia beranjak dari era telekomunikasi menuju era komunikasi interaktif (Rogers, 1986). Era komunikasi interaktif membuat internet tidak hanya dapat digunakan sebagai sarana mencari informasi, tetapi juga sebagai sarana untuk berinteraksi. Salah satu ruang yang diberikan oleh internet adalah melalui situs jejaring sosial. Situs jejaring sosial memungkinkan individu untuk menciptakan jaringan komunikasi dengan individu lain melalui sebuah sistem yang memiliki karakteristik tersendiri, bergantung pada karakteristik situs tersebut.

Jejaring sosial mempunyai keunikan untuk memungkinkan individu berbagi informasi didalamnya dan membuat jejaring sosialnya tampak nyata (Boyd, 2007). Penjabaran tersebut menjelaskan bahwa saat ini telah tercipta sebuah kebiasaan baru manusia dalam berinteraksi. Saat ini manusia tidak lagi harus bertemu secara fisik untuk dapat berinteraksi. Internet dan jejaring sosial telah memberikan sebuah media bagi manusia untuk dapa berinteraksi. Hal ini membuat 
internet menjadi sangat populer di Indonesia dan juga di seluruh dunia.

Salah satu segmen masyarakat yang menjadi pengakses informasi melalui internet paling kentara adalah generasi muda. Data survei juga mengungkap bahwa rata-rata pengakses internet di Indonesia menggunakan perangkat genggam. Statistiknya sebagai berikut:67,2 juta orang atau 50,7 persen mengakses melalui perangkat genggam dan komputer, 63,1 juta orang atau 47,6 persen mengakses dari smartphone dan 2,2 juta orang atau 1,7 persen mengakses hanya dari komputer (Widiartanto, 2016). Artinya, dapat dikatakan bahwa segmen pengguna internet di Indonesia adalah mereka yang termasuk ke dalam kategori 'digital natives'.

Digital natives adalah generasi yang lahir setelah tahun 1980 dan mempunyai karakteristik fasih menggunakan perangkat multimedia seperti perangkat genggam, HP/smartphone, laptop/computer. Kategori usia ini memiliki karakter yang sangat aktif menggunakan jejaring tehnologi digital dan memiliki kecakapan dalam mengoperasikan teknologi berbasis internet. Apabila kita kaitkan dengan teori generasi berdasarkan tahun kelahiran, maka mayoritas pengguna internet di Indonesia merupakan Generasi X, Y dan Z yang merupakan anak-anak muda di bawah usia 35 tahun.

Perbedaan tahun kelahiran merupakan salah satu penyebab antar generasi memiliki perilaku informasi yang berbeda karena setiap generasi hidup pada era perkembangan jaman yang berbeda, termasuk perkembangan teknologi informasi. Saat menjelaskan mengenai tipe-tipe generasi yang ada di dunia saat ini, fokusnya adalah sebagian besar pada lima generasi berikut: Veteran lahir sebelum 1945, Baby Boomers 1945-1960, Generasi X 1961-1980, Generasi Y 19811994, dan Generasi Z lahir setelah 1995 sampai sekarang (Richardson, 2012).

Perbedaan tahun kelahiran merupakan salah satu penyebab antar generasi memiliki perilaku informasi yang berbeda, sebab setiap generasi hidup pada era perkembangan jaman yang berbeda, termasuk perkembangan teknologi informasi. Setiap masa memiliki budaya, tingkat pemanfaatan teknologi yang berbeda serta gaya hidupyang berbeda (Hakim, 2010).

Generasi tua di Indonesia adalah generasi yang lahir sebelum teknologi masuk dan berkembang di Indonesia, hal itu merupakan salah satu penyebab sebagian dari generasi tua di Indonesia cenderung tertinggal dalam penggunaan dan pemanfaatan teknologi, terutama dalam mengakses kebutuhan informasi ilmiahnya. Hakekatnya manusia di dunia terbagi atas beberapa kategori generasi, setiap ahli informasi mempunyai kategori yang berbeda dalam mengkategorikan generasi manusia, tetapi pada umumya mereka mengkategorikan generasi manusia berdasarkan awal tahun kelahirannya.

Generasi pertengahan di Indonesia adalah generasi yang lahir ketika perkembangan teknologi baru masuk di
Indonesia, sedangkan di negara maju teknologi sudah marak dan ramai digunakan, sebab itu perbedaan perkembangan teknologi berpengaruh pada penggunaan dan pemanfaatan teknologi bagi generasi di Indonesia dalam mengakses kebutuhan informasi ilmiahnya, sedangkan generasi muda di Indonesia lahir ketika teknologi sudah sangat berkembang di Indonesia, sehingga hampir sebagian generasi muda menganggap teknologi merupakan bagian dari aktivitas dan kehidupan sehari-harinya.

Sektor pariwisata sebagai salah satu penyokong devisa negara ikut mengalami kemajuan yang cukup pesat di era globalisasi dan keterbukaan informasi ini. Pilihan akses informasi calon wisatawan di Indonesia semakin beragam. Akses informasi wisata melalui media internet sangat dominan dilakukan calon wisatawan yang akan berkunjung di suatu obyek wisata.

Berangkat dari beberapa fenomena tersebut, peneliti tertarik untuk mengkaji secara lebih dalam tentang sejauh mana dinamika akses informasi antar generasi yang berbeda dalam memenuhi kebutuhan informasi. Fokus dalam riset ini adalah meneliti bagaimana dinamika akses informasi wisatawan antar Generasi pada obyek wisata minat khusus atau Special Interest Tourism di Kabupaten Bantul. Pariwisata minat khusus atau Special Interest Tourism merupakan konsep pariwisata baru yang berfokus pada pencarian atraksi baru, alternatif, produk yang unik dan berkualitas, serta produk yang otentik/asli (Fandeli, 2000).

Pemilihan destinasi wisata minat khusus di Bantul difokuskan pada 10 lokasi obyek wisata yakni: Air Terjun Banyunibo di Pajangan, Hutan Pinus Mangunan, Jembatan Gantung Siluk Imogiri, Gumuk Pasir Geospasial Pesisir Parangtritis, Puncak Becici di Dlingo, Curug Pulosari di Pajangan, Watu Lumbung Parangtritis, Puncak Tri Panjung Dlingo, Sendang Lepo Dlingo, dan Puncak Kebun Buah Mangunan.

\section{LITERATURE REVIEW}

Informasi Komunikasi (TIK) dan Pariwisata

Perkembangan Teknologi Informasi Komunikasi (TIK) memiliki dampak yang cukup signifikan dalam dunia pariwisata global. Salah satu hal yang sangat kentara adalah adanya proses digitalisasi mata rantai dalam sektor pariwisata yang meliputi: agen perjalanan, perhotelan, ticketing, bisnis, promosi pemasaran ODTW, dan perilaku akses informasi wisatawan. Semua itu terintegrasi dengan satu perangkat TIK yang sangat mumpuni di era sekarang ini.

TIK sangat menunjang perkembangan pariwisata di berbagai belahan negara. Arus informasi dan komunikasi dapat dilakukan dengan sangat cepat, efisien dan akurat. TIK berkembang terus-menerus dan memberikan piranti- piranti baru dalam pariwisata. Beragam jenis TIK digunakan dalam dunia pariwisata. Penggunaan telepon genggam, saluran internet, Global Positioning System (GPS), kamera digital, radio digital, pemutar media digital merupakan salah satu contoh penggunaan TIK dalam pariwisata. 
Penggunaan software dan perangkat piranti lunak sebagai bagian dari perkembangan TIK juga sudah diterapkan dalam mengelola bisnis perhotelan. Sistem informasi hotel yang berbasis TIK digunakan untuk memberikan kepastian pemesanan kamar, kepastian rekening tamu, informasi tamu yang akan datang ke hotel, tamu yang sedang tinggal di hotel dan tamu yang akan meninggalkan hotel. Informasi yang cepat, tepat dan akurat. Pariwisata sebagai salah satu bagian aspek strategis suatu negara sangat memerlukan pengembangan multimedia, teknologi komunikasi dan sistem informasi untuk menjalankan roda kehidupannya (Sheldon, 1993).

Information Seeking Behavior/ Perilaku Mencari Informasi

Informasi merupakan kontributor kunci untuk pengembangan individu dan masyarakat. Orang membutuhkan informasi untuk mengembangkan potensi mereka, untuk sukses dalam bisnis, untuk memperkaya mereka pengalaman budaya, dan untuk mengendalikan mereka sehari-hari hidup. Orang selalu membutuhkan informasi untuk menjalankan berbagai kehidupannya. Salah satu yang menarik untuk ditelaah lebih lanjut yakni bagaimana pola perilaku pencarian informasi yang dilakukan.

Perilaku mencari informasi merupakan kegiatan seseorang ketika mengidentifikasi kebutuhan mereka sendiri untuk mencari informasi tersebut dengan cara apapun, dan menggunakan atau mentransfer informasi tersebut (Wilson, 2006). Proses akses informasi yang mencangkup aktivitas Information Seeking Behavior dan aktivitas Information Searching Behavior, dalam bahasa Indonesia kata seeking dan searching mempunyai persamaan arti kata, yaitu sama-sama berarti mencari.

Information Seeking Behavior yaitu suatu aktivitas yang dilakukan pencari informasi dalam upaya menemukan sumber informasi tertentu melalui media tertentu untuk memenuhi kebutuhan informasinya (Atmi, 2014). Proses pencarian informasi tersebut menggunakan beragam cara atau media yang dianggap dapat membantu dalam memenuhi kebutuhan informasinya. Baik melalui media cetak, elektronik, maupun media interaktif yang sekarang ini berkembang pesat seperti penggunaan TIK.

Aktivitas yang dilakukan oleh para pencari informasi merupakan upaya untuk mendapatkan informasi melalui interaksi dengan media baik secara elektronik maupun non elektronik. Pencari informasi menggunakan strategi khusus dalam upaya mendapatkan kebutuhan informasinya dengan tujuan mendapatkan hasil pencarian yang lebih efektif dan efisien. Fokus pada penelitian ini adalah dinamika akses informasi antar generasi yang sudah dibagi dalam beberapa kategori generasi: generasi baby boomers, $\mathrm{X}, \mathrm{Y}$, dan generasi $\mathrm{Z}$.

\section{Teori Antar Generasi}

Saat ini dunia sudah memasuki era baru yaitu "Internet Era” dimana pada era ini semua perangkat yang ada di sekitar kita saling terhubung dengan internet. Internet membawa dampak yang luar biasa bagi penggunanya. Dampak yang signifikan terlihat pada pola perilaku akses informasi pada generasi manusia di seluruh dunia, terutama dalam mencari dan mendapatkan jenis kebutuhan informasinya, baik informasi hiburan, informasi kesehatan, informasi pendidikan, informasi publik maupun informasiinformasi lainnya.

Generasi adalah sekelompok orang yang mempunyai karakteristik yang berbeda antara satu dengan yang lainnya, karakteristik tersebut yaitu perbedaan tahun kelahiran antara kelompok satu dengan kelompok lainya. Perbedaan tahun kelahiran merupakan salah satu penyebab antar generasi memiliki perilaku informasi yang berbeda, sebab setiap generasi hidup pada era perkembangan jaman yang berbeda, termasuk perkembangan teknologi informasi.

Pembagian antar generasi manusia ditulis tentang berdasarkan demografi yang dibentuk kelompok berdasarkan umur tertentu. Pembagian generasi tersebut dibagi menjadi Generasi Baby Boomers lahir pada tahun 1946 - 1964, Generasi X lahir lahir pada tahun 1965 - 1976, Generasi Y lahir lahir pada tahun 1977 - 1994, dan Generasi Z lahir lahir pada tahun 1995sekarang (Richardson, 2012). Perbedaan generasi berakibat pada perilaku akses informasi pada masingmasing generasi, setiap generasi memiliki persamaan maupun perbedaan perilaku pencarian informasi, seperti pola pencarian informasi, prosedur pencarian informasi, pemanfaatan media-media akses informasi, baik media online, media elektronik maupun media cetak serta penggunaan sumber informasi seperti sumber formal, sumber informal dan sumber-sumber informasi lainya.

Riset yang dilakukan oleh Gardiner pada tahun 2015 menunjukkan terdapat perbedaan dalam pola perjalanan dan perilaku wisatawa lintas generasi. Pada riset tersebut ditemukan perbedaan antara wisatawan Generasi Baby Boomer, Generasi X, Generasi Y, dan Generasi $Z$ dalam sumber informasi dan kegiatan yang disukai, tujuan, dan perjalanan mereka (Gardiner et al, 2015).

\section{Pariwisata Minat Khusus/Special Interest Tourism}

Seiring perkembangan pariwisata di Indonesia, berbagai macam wisata baru mulai diperkenalkan. Munculnya jenis wisata baru berasal dari berbagai faktor. Faktor utamanya adalah keinginan dari wisatawan untuk melakukan kegiatan wisata seorang diri atau membentuk grup-grup kecil demi kenyamanan atau privasi. Faktor lainnya dapat disebabkan oleh keinginan wisatawan untuk dapat menyalurkan kesenangannya dengan bentuk wisata yang sesuai dengan kepribadian atau hobinya. Jenis wisata ini dikenal dengan wisata minat khusus. Wisata ini cenderung menggunakan tempat atau menampilkan atraksi wisata yang unik dan lebih spesifik.

Pariwisata minat khusus menurut Fandeli (2000), 
dapat terfokus pada (i) aspek budaya, di antaranya: tarian/musik/ seni tradisional, kerajinan, arsitektur, pola tradisi masyarakat, aktivitas ekonomi yang spesifik, arkeologi dan sejarah, serta (ii) aspek alam, di antaranya: kekayaan flora-fauna, gejala geologi, keeksotikan taman nasional, hutan, sungai, air terjun, pantai, laut dan perilaku ekosistem tertentu.

Ada beberapa kriteria yang dapat dipergunakan sebagai pedoman dalam menetapkan suatu bentuk wisata minat khusus, yaitu adanya unsur: Learning, yaitu kegiatan wisata yang mengarah pada unsur pembelajaran; Rewarding, yaitu kegiatan wisata yang memasukkan unsur pemberian penghargaan atau mengagumi keindahan/ keunikan kekayaan dari suatu atraksi yang kemudian menimbulkan penghargaan; Enriching, yaitu pariwisata yang memasukkan peluang terjadinya pengayaan pengetahuan masyarakat; dan Adventuring, yaitu pariwisata yang dirancang sebagai wisata petualangan (Fandeli, 2000).

\section{METODE PENELITIAN}

Penelitian ini menggunakan pendekatan kuantitatif. Metode penelitian yang digunakan adalah metode survei. Metode ini dianggap lebih menguntungkan untuk suatu populasi yang besar dimana dalam penelitian survei, akan diambil sampel yang merepresentasikan populasi seluruhnya. Hasil penelitian cenderung untuk digeneralisasikan
(Sugiyono, 2013).

Pengumpulan data dalam penelitian ini menggunakan kuesioner dan observasi. Kuesioner bisa menjadi alat pengumpulan data yang efisien karena jumlah informan/responden dalam penelitian ini cukup besar dan tersebar dalam wilayah yang luas, sedangkan observasi dilakukan untuk memperoleh informasi yang berkenaan dengan perilaku manusia, proses kerja, maupun gejala-gejala alam (Sugiyono, 2010).

Penelitian ini menggunakan 2 (dua) model analisis data yang ada pada software statistik SPSS, yakni metode statistik distribusi frekuensi dan tabel silang/crosstabs. Distribusi frekuensi dilakukan dengan proses perhitungan dan peringkasan data agar dapat dipahami dan diinterpretasikan secara baik. Hal ini sekaligus untuk membantu peneliti mengetahui bagaimana jumlah berbagai sub-kategori dari suatu fenomena yang terjadi (Sekaran, 2006).

Lokasi dalam penelitian ini mengambil tempat di obyek wisata minat khusus di Kabupaten Bantul (lihat tabel 1.1). Pemilihan lokasi tersebut didasarkan pada pertimbangan bahwa lokasi tersebut merupakan obyek wisata yang baru berkembang di wilayah Kabupaten Bantul. Lokasi ini memiliki banyak potensi untuk bisa dikembangkan menjadi obyek wisata unggulan. Sampel yang diteliti adalah wisatawan yang datang ke semua lokasi penelitian selama kurun waktu Mei-September 2016.

Tabel 1.1 Lokasi Penelitian

\begin{tabular}{|r|l|l|}
\hline No. & Nama Obyek Wisata & Alamat \\
\hline 1 & Air Terjun Banyu Nibo & Pajangan, Bantul \\
\hline 2 & Hutan Pinus Mangunan & Mangunan, Dlingo \\
\hline 3 & Jembatan Gantung Siluk & Siluk, Imogiri \\
\hline 4 & Gumuk Pasir Geospasial & Parangtritis \\
\hline 5 & Puncak Becici & Dlingo \\
\hline 6 & Curug Pulosari & Pajangan \\
\hline 7 & Watu Lumbung & Parangtritis \\
\hline 8 & Puncak Tri Panjung & Dlingo \\
\hline 9 & Sendang Lepo & Dlingo \\
\hline 10 & Puncak Kebun Buah & Mangunan, Dlingo \\
\hline
\end{tabular}

Pengambilan sampel menggunakan teknik non probably sampling karena jumlah populasi pada penelitian tidak diketahui secara pasti. Hal ini disebabkan belum adanya pendataan jumlah pengunjung obyek wisata oleh pemerintah setempat. Pengambilan sampel dilakukan selama bulan MeiSeptember 2016 di 10 lokasi penelitian yang sudah ditentukan. Sampel yang disebar sebanyak 200 sampel dengan masing-masing lokasi penelitian mendapat 20 kuesioner.

\section{HASIL DAN PEMBAHASAAN}

Penelitian ini diawali dengan membuat konsep tentang survei, menyusun kuesioner, menentukan lokasi-lokasi penelitian, menentukan banyaknya sampel minimal yang akan diambil, menyebar angket, kemudian menarik angket, mengedit dan melakukan koding angket, melakukan entri data pada software analisa statistik, dan melakukan analisa statistika berdasar kaedah statistika yang benar. 
Profil dan Karakteristik Pengunjung

Belum adanya pendataan jumlah pengunjung di 10 obyek wisata yang dijadikan lokasi penelitian oleh pemerintah setempat, maka ukuran sampel minimal diperoleh yakni sebanyak 100 orang di 10 lokasi penyebaran angket. Dalam penelitian ini ukuran sampel digandakan menjadi 200 orang agar hasil penelitian semakin valid. Tabel 1.2. memberikan informasi tentang karakteristik dari 200 responden yang diambil.

Dari tabel 1.3 menunjukkan sebaran responden berdasarkan asal daerah dan status perkawinan. Sebagian besar responden yang diberi angket berasal dari dalam kota Yogyakarta (55 \%) dan merupakan wisatawan yang masih lajang / belum menikah (82\%).

Tabel 1.2. Data Responden

\begin{tabular}{|l|c|c|}
\hline Distribusi Sampel & Jumlah & Persentase \\
\hline $\begin{array}{l}\text { Lokasi Penyebaran } \\
10 \text { lokasi }\end{array}$ & & \\
\cline { 2 - 3 } & 200 & $100 \%$ \\
\hline $\begin{array}{l}\text { Jenis Kelamin } \\
\text { Laki-laki }\end{array}$ & & \\
Perempuan & 100 & $50 \%$ \\
\hline $\begin{array}{l}\text { Usia } \\
<21 \text { tahun } \\
22-39 \text { tahun } \\
40-51 \text { tahun } \\
52-71 \text { tahun }\end{array}$ & 100 & $50 \%$ \\
\cline { 2 - 3 } & 90 & $45 \%$ \\
\cline { 2 - 3 } & 24 & $41 \%$ \\
\hline
\end{tabular}

Selanjutnya, tabel 1.4. menunjukkan sebaran responden berdasarkan jenjang pendidikan dan pekerjaan. Mayoritas responden yang datang berpendidikan SMA (54 \%) dan kuliah / D3/D4/S1/S2 (44\%). Sedangkan dari jenis pekerjaan, mayoritas responden bermata pencaharian sebagai pelajar/mahasiswa yakni sebanyak $66 \%$. Sisanya merupakan karyawan BUMN/swasta (23\%), wirausaha (5\%), PNS (4\%), dan lain-lain (2\%).

Pada tabel 1.5. menunjukkan 60 orang atau $30 \%$ wisatawan merupakan wisatawan yang bergerak secara individu atau bersama pasangan. Kemudian 140 orang atau $70 \%$ merupakan wisatawan yang bergerak secara kelompok / banyak orang.

Tabel 1.3. Distribusi responden dari asal daerah dan status perkawinan

\begin{tabular}{|l|c|c|c|c|}
\hline \multirow{2}{*}{ Distribusi Sampel } & Frequency & Percent & Valid & Cumulative \\
\hline Dalam kota & 110 & 55.0 & 55.0 & 55.0 \\
\hline Luar kota & 90 & 45.0 & 45.0 & 100.0 \\
\hline Total & 200 & 100.0 & 100.0 & \\
\hline Lajang & 164 & 82.0 & 82.0 & 82.0 \\
\hline Menikah & 36 & 18.0 & 18.0 & 100.0 \\
\hline Total & 200 & 100.0 & 100.0 & \\
\hline
\end{tabular}

Tabel 1.4 Distribusi responden berdasarkan Pendidikan dan Pekerjaan

\begin{tabular}{|l|r|r|r|r|}
\hline Distribusi Sampel & Frequency & Percent & Valid Percent & $\begin{array}{c}\text { Cumulative } \\
\text { Percent }\end{array}$ \\
\hline SMP & 4 & 2.0 & 2.0 & 2.0 \\
\hline SMA & 108 & 54.0 & 54.0 & 56.0 \\
\hline D3/S1/S2 & 88 & 44.0 & 44.0 & 100.0 \\
\hline Total & 200 & 100.0 & 100.0 & \\
\hline PNS & 8 & 4.0 & 4.0 & 4.0 \\
\hline Wirausaha & 10 & 5.0 & 5.0 & 9.0 \\
\hline $\begin{array}{l}\text { Karyawan BUMN/ } \\
\text { Swasta }\end{array}$ & 46 & 23.0 & 23.0 & 32.0 \\
\hline Pelajar/Mahasiswa & 132 & 66.0 & 66.0 & 98.0 \\
\hline Lain-lain & 4 & 2.0 & 2.0 & 100.0 \\
\hline Total & 200 & 100.0 & 100.0 & \\
\hline
\end{tabular}


Tabel 1.5. Distribusi responden berdasarkan bentuk kunjungan

\begin{tabular}{|l|c|c|c|}
\hline \multirow{2}{*}{$\begin{array}{c}\text { Nama obyek } \\
\text { wisata }\end{array}$} & \multicolumn{2}{|c|}{ Bentuk kunjungan } & \multirow{2}{*}{ Total } \\
\cline { 2 - 3 } & Individu & Kelompok & \\
\hline Air Terjun Banyunibo & 10 & 10 & 20 \\
\hline Hutan Pinus Imogiri & 0 & 20 & 20 \\
\hline Jembatan Gantung Imogiri & 8 & 12 & 20 \\
\hline Gumuk Pasir Parangtritis & 4 & 16 & 20 \\
\hline Puncak Becici & 6 & 14 & 20 \\
\hline Curug Pulosari Pajangan & 2 & 18 & 20 \\
\hline Watu Lumbung & 8 & 12 & 20 \\
\hline Puncak Tri Panjung & 12 & 8 & 20 \\
\hline Sendang Lepo Dlingo & 6 & 14 & 20 \\
\hline Puncak Mangunan & 4 & 16 & 20 \\
\hline Total & 60 & 140 & 200 \\
\hline
\end{tabular}

\section{Dinamika Akses Informasi Wisatawan}

Hasil penyebaran angket ke responden didapatkan data bahwa mayoritas wisatawan yang datang menggunakan internet sebagai sumber informasi yang dibutuhkan untuk diakses sebelum berkunjung ke obyek wisata.
Mayoritas yang memilih internet ada pada generasi muda yakni berumur kurang dari 40 tahun. Sejumlah 126 orang atau $88.8 \%$ dari pengakses internet ada pada rentang usia dibawah 21 tahun dan antara 22-39 tahun. Sisanya merata pada usia diatas 40 tahun (lihat gambar 1.1 berikut).

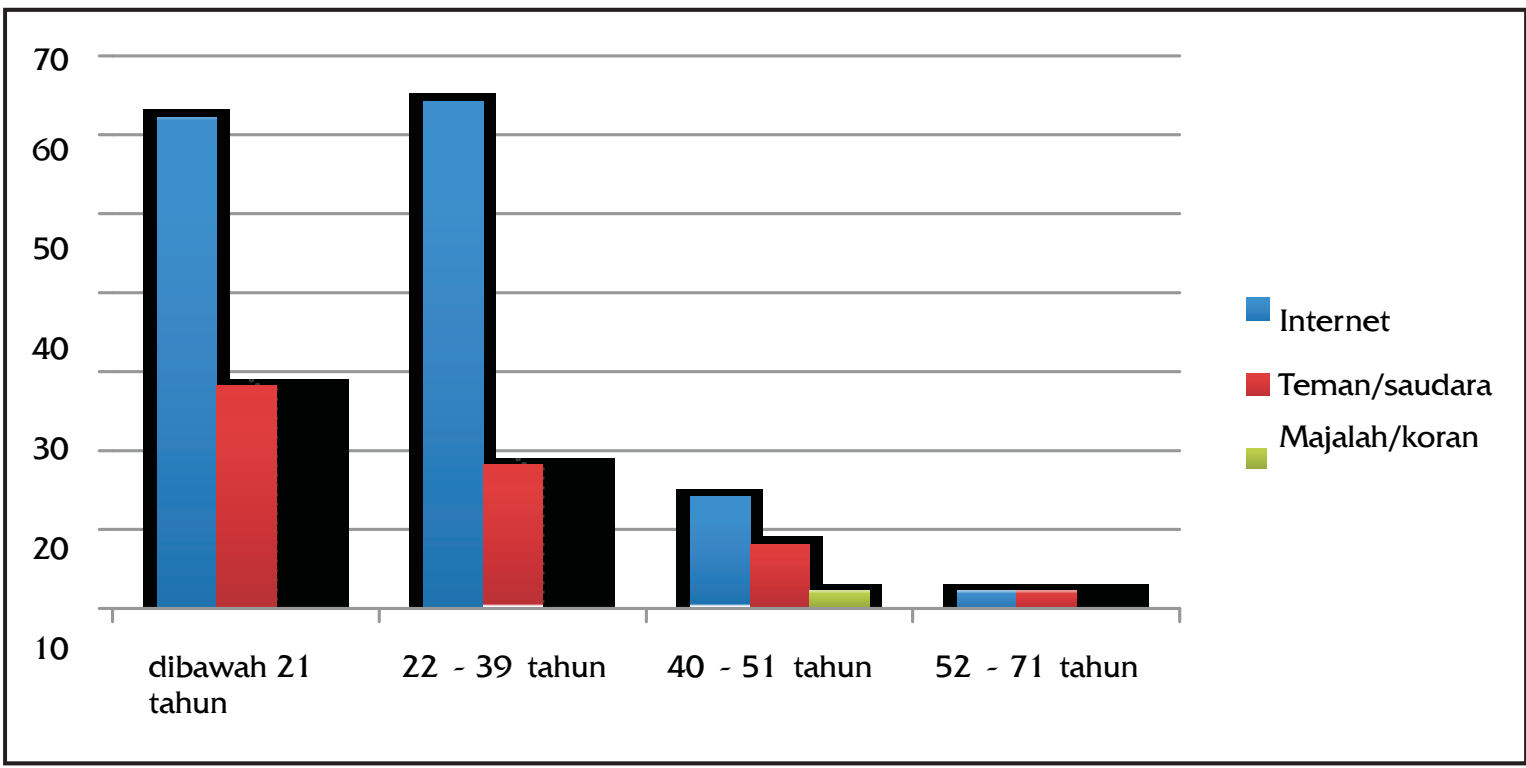

Gambar 1.1. Sumber informasi wisatawan

Berdasarkan media apa yang diakses oleh responden sebelum berkunjung ke obyek wisata, data kuesioner menjunjukkan bahwa media instagram merupakan media yang paling banyak diakses oleh wisatawan. Rata-rata pengakses instagram ada pada rentang usia dibawah 40 tahun. Tercatat sebanyak 110 orang atau $55 \%$ merupakan pengakses instagram. Rentang usia dibawah 21 tahun tercatat sebanyak 60 orang atau $54.5 \%$. Kemudian rentang usia 22-39 tahun berada pada angka 48 orang atau $43.6 \%$ (lihat gambar 1.2 berikut). 


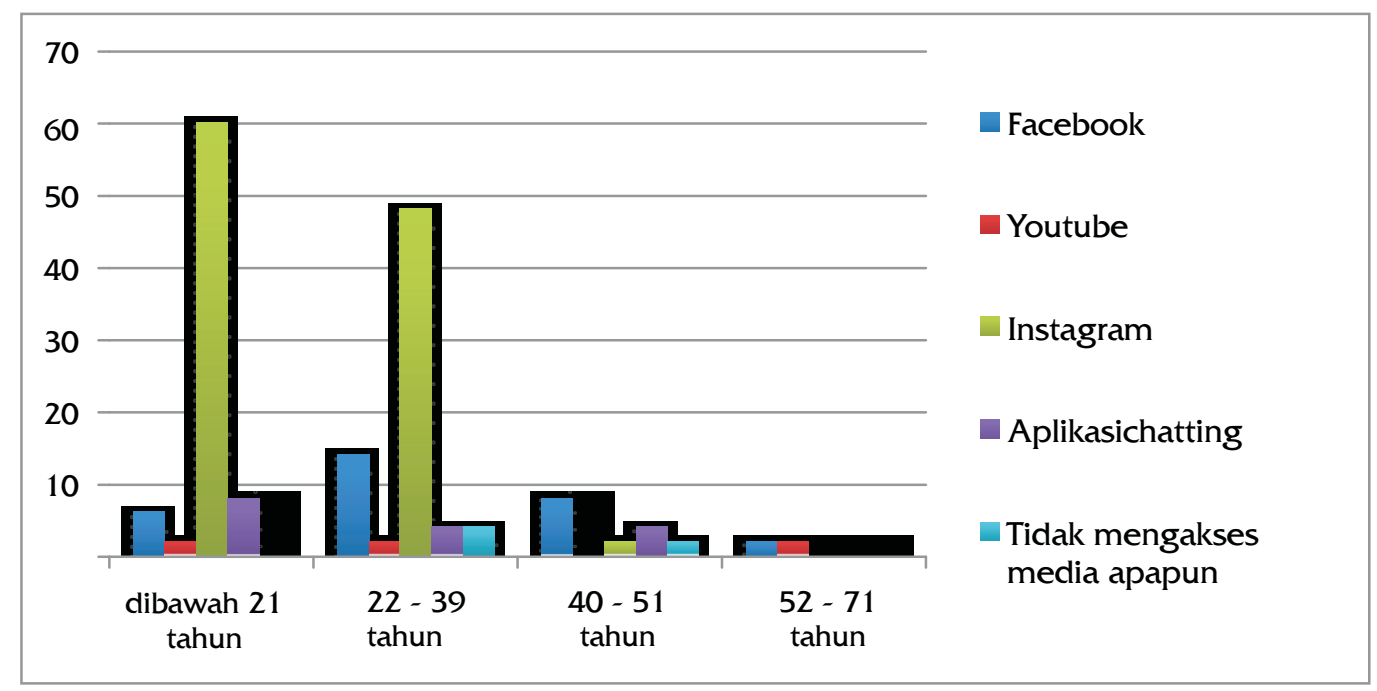

Gambar 1.2. Media yang diakses

Apabila kita lihat pada bagian perangkat apa yang digunakan wisatawan untuk mengakses media, maka muncul jawaban paling banyak adalah memakai handphone/smartphone. Data kuesioner menunjukkan bahwa sejumlah 162 orang dari 200 orang responden yang menjawab memakai HP sebagai piranti akses. Sejumlah 78 orang atau $48.1 \%$ ada pada rentang usia dibawah 21 tahun, sedangkan 66 orang atau $40.7 \%$ ada pada rentang usia 22-39 tahun. Generasi muda yakni para generasi $Z$ dan $Y$ yang merupakan generasi milenial memang menjadi generasi yang paling addicted terhadap media dan informasi (lihat gambar 1.3 berikut untuk data lebih lengkap).

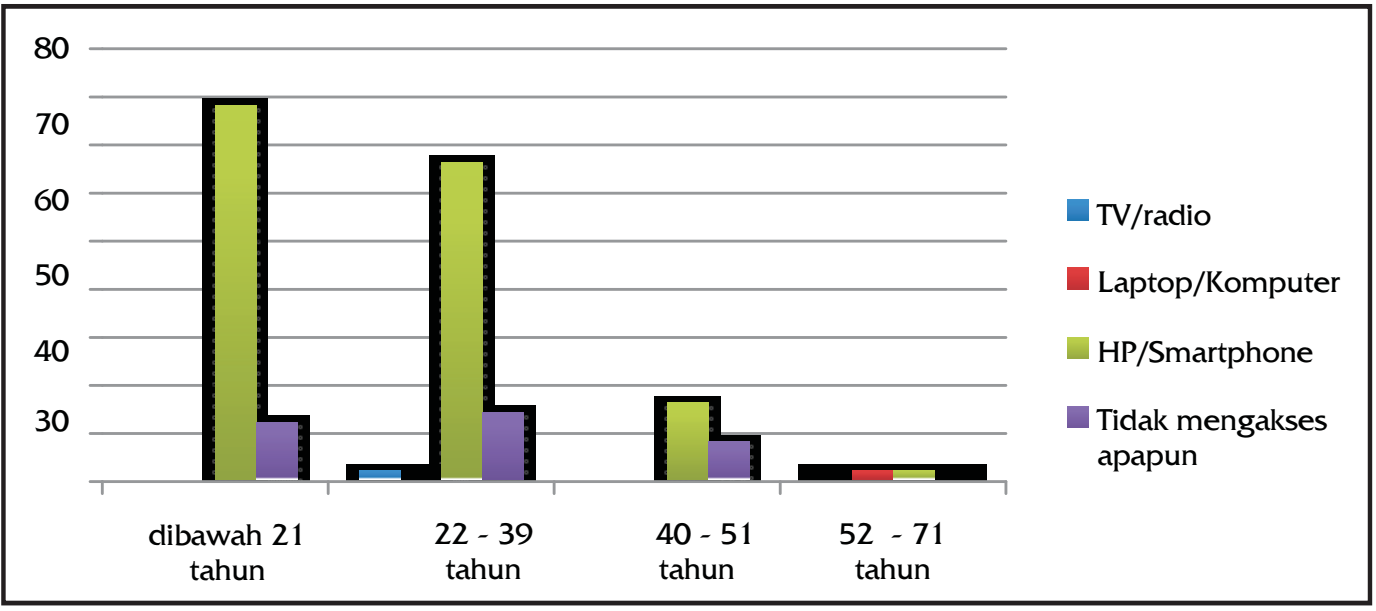

Gambar 1.3. Perangkat yang digunakan

Berdasarkan analisis skala likert, mayoritas wisatawan yang menjawab mengakui bahwa pengaruh internet dewasa ini sangat besar manfaatnya dalam dunia pariwisata ketika wisatawan akan berkunjung di suatu obyek wisata (lihat gambar 1.4 berikut untuk data lebih lengkap).

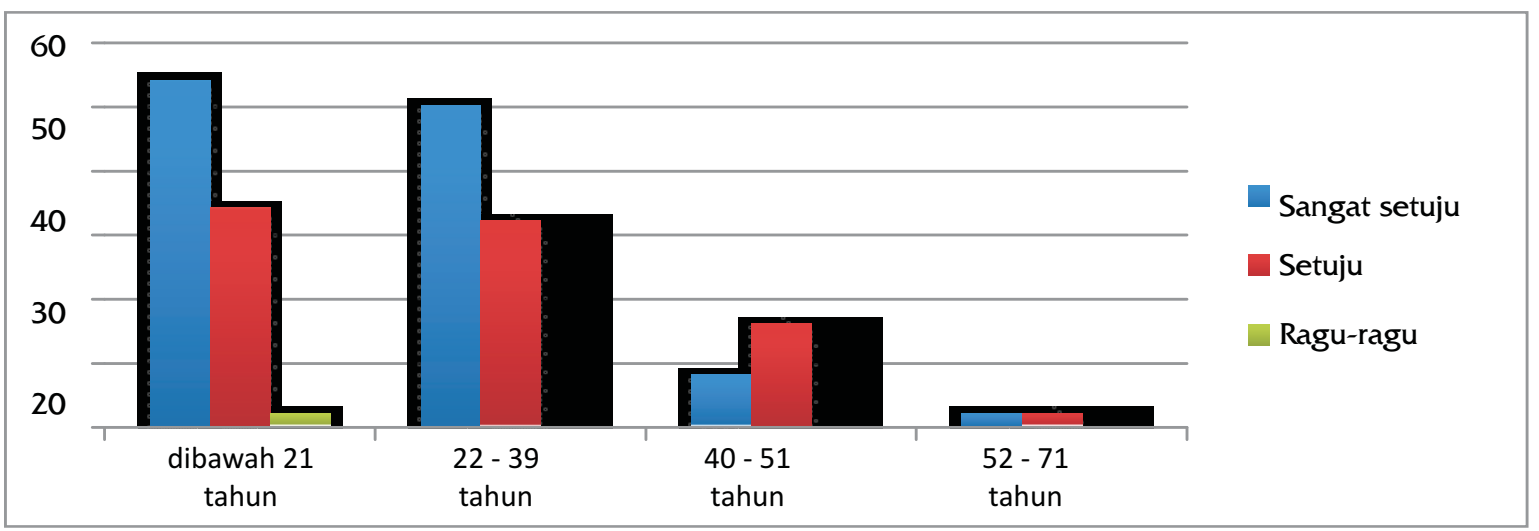

Gambar 1.4. Analisis skala likert 


\section{KESIMPULAN}

Berdasarkan hasil pembahasan yang telah ditulis, ada beberapa kesimpulan dari penelitian/riset ini:

1. Mayoritas wisatawan yang berkunjung di lokasi penelitian berada pada rentang usia dibawah 21 tahun (generasi Z) dan usia antara 22 - 39 tahun (generasi Y).

2. Mayoritas wisatawan yang berkunjung di lokasi penelitian menggunakan internet sebagai sumber informasi yang dibutuhkan untuk diakses sebelum berkunjung ke obyek wisata. Sebagian besar berada pada rentang usia dibawah 21 tahun (generasi Z) dan usia antara 22 - 39 tahun (generasi Y).

3. Mayoritas wisatawan yang berkunjung di lokasi penelitian menjunjukkan bahwa media instagram merupakan media yang paling banyak diakses oleh wisatawan terutama pada rentang usia dibawah 21 tahun (generasi Z) dan usia antara 22 - 39 tahun (generasi Y).

4. Mayoritas wisatawan yang berkunjung di lokasi penelitian mengaku memakai handphone/ smartphone sebagai alat untuk mengakses informasi yang dibutuhkan sebelum berkunjung ke obyek wisata. Sebagian besar ada pada rentang usia dibawah 21 tahun (generasi Z) dan usia antara 22 39 tahun (generasi Y). Generasi muda yakni para generasi $\mathrm{Z}$ dan $\mathrm{Y}$ yang merupakan generasi milenial memang menjadi generasi yang paling addicted terhadap media dan informasi.

5. Mayoritas wisatawan yang menjawab mengaku bahwa pengaruh internet dewasa ini sangat besar manfaatnya dalam dunia pariwisata ketika wisatawan akan berkunjung di suatu obyek wisata.

\section{REKOMENDASI}

Setelah memaparkan hasil kesimpulan, saran-saran berikut ini dapat dipertimbangkan.:

1. Pengelola obyek wisata dan stakeholder di Kabupaten Bantul harus menyadari bahwa pengaruh internet dewasa ini sangat besar manfaatnya dalam dunia pariwisata.

2. Pengelola obyek wisata dan stakeholder terkait harus memperhatikan para generasi muda pada rentang usia dibawah 21 tahun (generasi $Z$ ) dan usia antara 22 - 39 tahun (generasi Y) sebagai calon wisatawan yang sangat potensial.

3. Pengelola obyek wisata dan stakeholder terkait harus melihat bahwa generasi muda yakni para generasi $\mathrm{Z}$ dan $\mathrm{Y}$ yang merupakan generasi milenial memang menjadi generasi yang paling addicted terhadap media dan informasi.

\section{DAFTAR PUSTAKA}

Atmi, Ragil Tri. 2014. Dinamika Akses Informasi Ilmiah Pada Pemustaka Perpustakaan Pusat UGM. Thesis: Universitas Gadjah Mada.

Boyd, M. Danah. 2007. Social Networks Sites: Definition History and Scholarship. Journal of Computer Mediated Communication, University of CaliforniaBerkeley. Vol. 13 No 1 pp 210-230.

Fandeli, Chafid dan Mukhlison. 2000. Pengusahaan Ekowisata. Yogyakarta: Fakultas Kehutanan UGM dan BKSDA Yogyakarta.

Gardiner, Sarah dan Debra Grace. 2015. Is the Australian domestic holiday a thing of the past? Understanding baby boomer, Generation $X$ and Generation Y perceptions and attitude domestic and international holidays. Journal of Vacation Marketing, Volume 21 No. 4 pp 336-350.

Hakim, H. 2010. Perpustakaan Hibrida Berbasis Web 20 : Format Perpustakaan di Era Milenium (internet). Thesis: Universitas Indonesia.

Richardson, Chauncey T. 2012. A Study of Generation X and $Y$ Perception of The Customer Experience when Purchasing Airline Travel. Dissertation: Capella University USA.

Rogers, Everett M. 1986. Communication Technology: The New Media in Society. New York: The Free Press.

Sekaran, 2006. Metodologi Penelitian Untuk Bisnis. Jakarta: Salemba Empat.

Sheldon, P. J. 1993. Destination Information Systems. Annals of Tourism Research, Vol 20, No. 2 pp 633-649.

Sugiyono. 2010. Metodologi Penelitian Pendidikan: Pendekatan Kuantitatif Kualitatif, dan R \& D. Bandung: Alfabeta.

Sugiyono. 2013. Cara Mudah Menyusun Skripsi, Tesis dan Disertasi. Bandung: Alfabeta.

Widiartanto, Yoga Hastyadi. 2016. Pengguna Internet di Indonesia Capai 132 Juta. Kompas, 24 Oktober 2016.

Wilson, T.D,. 2006. On User Studies and Information Needs. Journal of Information and Knowledge Management, Vol 62, No. 6, pp 658- 